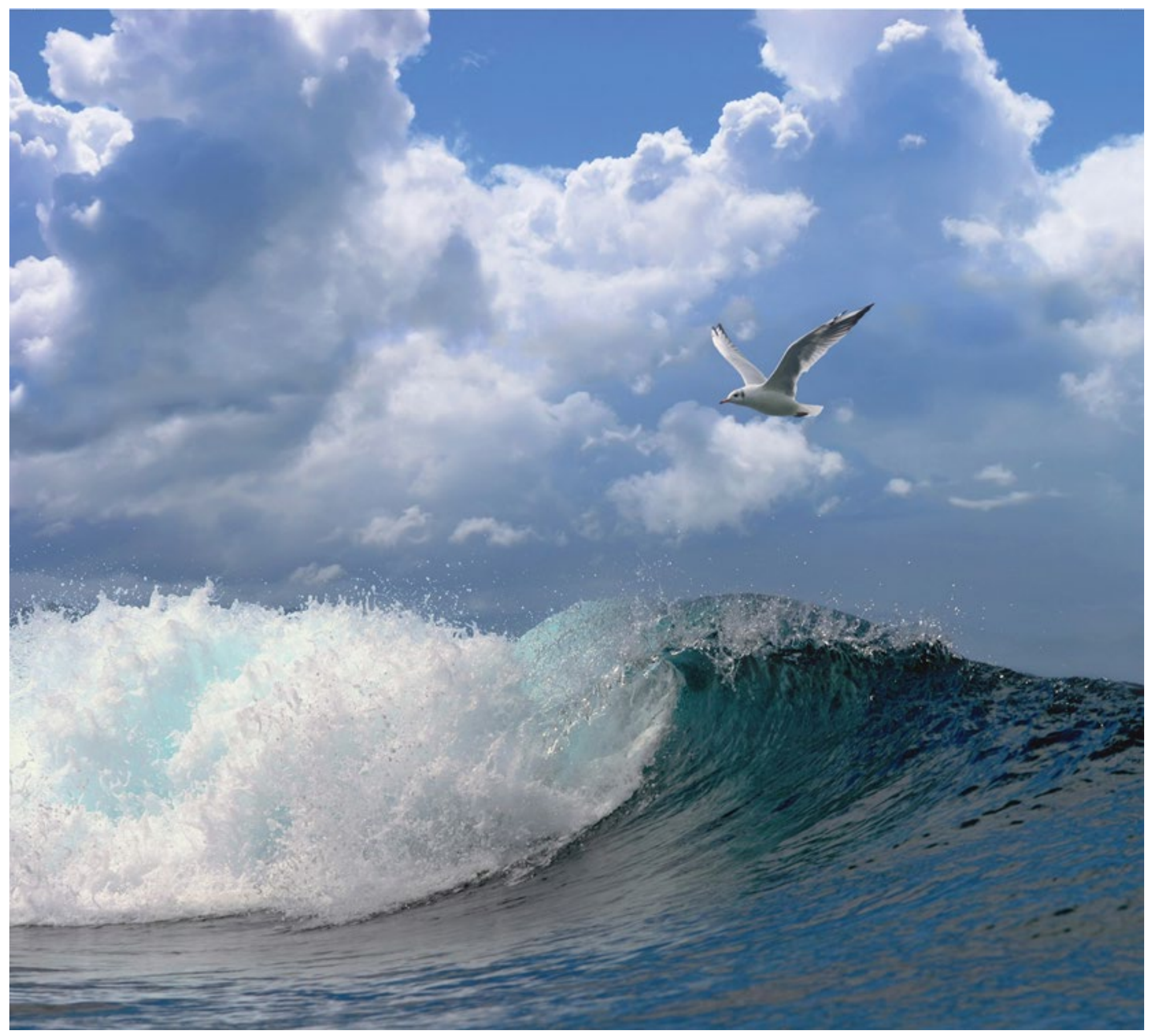

Spatial dynamics of pulse vessels: a preliminary analysis of the pulse logbook data collected in 2017 and 2018 


\section{Spatial dynamics of pulse vessels: a preliminary analysis of the pulse logbook data collected in 2017 and 2018}

Author(s): $\quad$ Adriaan Rijnsdorp, Geert Aarts, Daan Gerla, Jacco van Rijssel, Jan Jaap Poos

This research project was carried out by Wageningen Marine Research at the request of and with funding from the Ministry of Agriculture, Nature and Food Quality for the purposes of Policy Support Research Theme BO Nature inclusive Fisheries (project no. BO-43-023.02-004).

Wageningen Marine Research

IJmuiden, April 2019

Wageningen Marine Research report C030/19 
Keywords: fishing patterns, pulse trawl, beam trawl, fleet dynamics, fishing behaviour.

Client: $\quad$ Ministerie van LNV

Attn.: Maddalena Visser

Postbus 20401

2500 EK Den Haag

BO-43-023.02-004

This report can be downloaded for free from https://doi.org/10.18174/473663

Wageningen Marine Research provides no printed copies of reports

Wageningen Marine Research is ISO 9001:2015 certified.

\section{(C) Wageningen Marine Research}

Wageningen Marine Research, an institute Wageningen Marine Research accepts no liability for consequential damage, nor within the legal entity Stichting for damage resulting from applications of the results of work or other data Wageningen Research (a foundation under obtained from Wageningen Marine Research. Client indemnifies Wageningen Dutch private law) represented by Dr. Marine Research from claims of third parties in connection with this application. M.C.Th. Scholten, Managing Director All rights reserved. No part of this publication may be reproduced and / or

KvK nr. 09098104, published, photocopied or used in any other way without the written permission WMR BTW nr. NL 8113.83.696.B16.

Code BIC/SWIFT address: RABONL2U IBAN code: NL 73 RABO 0373599285 


\section{Contents}

$1 \quad$ Nederlandse samenvatting

2 Abstract

3 Introduction

6

$4 \quad$ Material and Methods $\quad 8$

$\begin{array}{lll}4.1 & \text { Logbook data } & 8\end{array}$

$\begin{array}{lll}4.2 & \text { Analysis of fishing patterns } & 8\end{array}$

4.2.1 Exploitation and searching tows $\quad 8$

4.2.2 Setting the distance criterion $\quad 9$

4.3 Catch rate during searching and exploitation 9

4.3.1 Decline in catch rate during exploitation $\quad 9$

4.4 Fishing patterns at the individual vessel level and the fleet level 10

5 Results $r$

$\begin{array}{lll}5.1 & \text { Fishing pattern of individual vessels } & 11\end{array}$

5.2 Fishing patterns at the level of the fleet 12

6 Discussion $\quad 13$

$\begin{array}{llr}7 & \text { Acknowledgments } & 15\end{array}$

$\begin{array}{llr}8 & \text { References } & 16\end{array}$

$\begin{array}{llr}9 & \text { Quality Assurance } & 27\end{array}$

$\begin{array}{lr}\text { Justification } & 28\end{array}$ 


\section{$1 \quad$ Nederlandse samenvatting}

Met ingang van 1 januari 2017 is een begin gemaakt met het registreren van de gedetailleerde vangstgegevens van de pulsschepen. WMR heeft de tot 30 september 2018 verzamelde gegevens geanalyseerd en het visgedrag van pulsschepen vergeleken met dat van traditionele boomkorschepen. Het belangrijkste resultaat van de voorlopige analyse is dat er boomkor- en pulsschepen hun visserijactiviteit concentreren op lokale visgronden waar het vangstsucces gemiddeld $30 \%$ hoger is. Tijdens de bevissing van een lokale visgrond neemt het vangstsucces af. De snelheid waarmee het vangstsucces afneemt is voor boomkorschepen groter dan voor pulsschepen. Ook blijven boomkorschepen minder lang op een lokale visgrond dan pulsschepen.

Doel van het logboekonderzoek is om inzicht te krijgen of het visgedrag van schippers is veranderd door de overgang van wekkertuigen naar pulstuigen. Voor het maatschappelijk debat over de pulsvisserij is het belangrijk te weten hoe vissers lokale visgronden bevissen en hoe het vangstsucces zich ontwikkeld zodat we op basis van feiten de voors en tegens kunnen afwegen. In totaal zijn de gegevens van 137 duizend trekken van 77 pulsschepen onderzocht. Van een aantal reizen konden de gegevens niet gebruikt omdat ze onvolledig waren of omdat er fouten in de gegevens zaten.

Het visgedrag van pulsschippers is vergeleken met dat van traditionele boomkorschippers waarvoor aan het begin van deze eeuw verzameld in het kader van het F-project dat WMR in samenwerking met de platvissector heeft uitgevoerd. De trekgegevens, waarbij de vispositie en de vangst van iedere trek is geregistreerd, laten zien dat tijdens een visreis een aantal zoektrekken afgewisseld wordt met een aantal exploitatie-trekken op een visgrond. Zoektrekken liggen ver uit elkaar en exploitatie-trekken liggen dicht bij elkaar. Het vangstsucces voor tong van de exploitatie-trekken op een visgrond is zo'n $30 \%$ hoger dan van de zoektrekken voor zowel de boomkor- als de pulsvisserij. Tijdens de bevissing van een lokale visgrond neemt het vangstsucces geleidelijk af. Voor de boomkorvisserij is de afnamesnelheid duidelijk hoger dan voor de pulsvisserij. Een boomkorvisser ziet zijn vangstsucces per etmaal gemiddeld $15 \%$ afnemen. Voor een pulsvisser nam het vangstsucces per etmaal met gemiddeld $7 \%$ (grote kotters) en $4 \%$ (Euro kotters) af. In lijn met de snellere afname van het vangstsucces bleven de boomkorschepen gemiddeld korter op een zelfde visgrond vissen dan pulsschepen. Van de visgronden van de pulsschepen werd $61 \%$ door één enkel vaartuig bevist en $39 \%$ door twee of meer vaartuigen.

De gepresenteerde resultaten zijn voorlopig en het onderzoek wordt voortgezet. De logboekgegevens geven de gedetailleerde informatie waarmee de lokale visgronden in kaart kunnen worden gebracht en waarmee kan worden onderzocht hoe de lokale visgronden worden geëxploiteerd. Deze informatie is belangrijk om de invloed van de pulskorvisserij op de visbestanden en op het bentische ecosysteem te beoordelen. De volgende stap zal zijn om de wekelijkse visserijpatronen van de hele vloot te analyseren en de interacties tussen visserijvaartuigen te bestuderen. 


\section{Abstract}

Knowledge on how fishers exploit their fisheries resources is important for understanding how fishing affect the population dynamics of the exploited species and how the fishery may affect the ecosystem. The introduction of a new gear may affect the way fishers deploy their gear in space and time. Here we present the results of a study of the spatial dynamics of pulse trawl vessels when exploiting local aggregations of sole. The behaviour of pulse trawl vessels is compared to the behaviour of traditional beam trawl vessels. Because the pulse logbook monitoring is still ongoing, the results are preliminary and will be updated when the complete data set will become available. The logbook data set analysed comprised catch and effort information per tow collected between 1 January 2017 and 30 September 2018. The results were compared with an analysis of logbook data of traditional beam trawl vessels collected between 2000 - 2005.

The study showed that pulse trawl (PT) and traditional beam trawl (BT) vessels had similar fishing patterns with alternating periods of searching, or sampling, for fishing grounds and exploitation of fishing grounds. The catch rate of sole during exploitation of a fishing ground was on average $22 \%$ (PT) and $23 \%$ (BT) higher than while searching for fishing grounds. PT deploy $73 \%$ of their tows while exploiting a fishing ground and $27 \%$ while searching or sampling, as compared to $69 \%$ and $31 \%$ in BT. The number of tows taken on a fishing ground by PT (large vessels: median $=16.4$; small vessels: median $=18.8$ ) was higher than by BT (median = 13.0). During an exploitation event - the period of successive tows made at a fishing ground - the sole catch rate declined over successive tows.

Although the rate of decline varied substantially among the different fishing grounds, the statistical analysis showed that on average the rate of decline was faster for BT than for PT. Of the pulse fishing grounds distinguished during the study period $61 \%$ were exploited by a single vessel and $39 \%$ were exploited by two or more vessels. Vessels differ in the proportion of fishing grounds shared with other vessels. Fishing effort on shared fishing grounds is higher than on the fishing grounds exploited by a single vessel only.

The logbook data provide detailed information on what happens on the local fishing grounds which is fundamental to assess the impact of the pulse trawl fishery and beam trawl fishery on the fisheries resources and on the benthic ecosystem. The study of the total pulse fleet provides a unique data set to study not only the dynamics of the whole fleet, including the interactions among pulse vessels, but also provides a solid basis to study competitive interactions with other fisheries. 


\section{Introduction}

Between 2009 and 2015, the Dutch beam trawl fleet targeting sole in the North Sea has switched from using the traditional tickler chain beam trawl to the electrified pulse trawl (Turenhout et al., 2016; Haasnoot et al., 2016). The pulse trawl requires less fuel to tow the gear over the sea floor and catches about 30\% more sole per hour fishing than the traditional beam trawl (Poos et al., in prep). Since the use of electricity in catching fish is prohibited in the EU, vessels operate under a (temporary) exemption. The legal basis of the exemptions and the number of licenses issued is given by (Haasnoot et al., 2016). In 2006, the EU introduced a derogation (under Annex III (4) of Council Regulation (EC) No. 41/2006) allowing 5\% (22 vessels) of the beam trawler fleet by Member States fishing in ICES zones IVc and IVb to use the pulse trawl on a restricted basis. In 2010 twenty additional licenses were issued based on Article 43,850/199820, and in 2014 another 42 licenses were issued based on Article 14. The exemptions were issued under the condition of scientific research to address the concerns expressed by ICES about the ecological impacts of pulse trawling and the implications for the sustainable exploitation of the target species.

One of the research programmes is collecting catch and effort data of all pulse trawlers when fishing for sole. The objective of the project is to obtain insight in how pulse fishers exploit flatfish resources on local fishing grounds and how this affects the catch efficiency. It is at the local scale that fishers impact the ecosystem and that fishers may compete with other fishers (Rijnsdorp et al., 2011; Branch et al., 2005; Eigaard et al., 2017; van Denderen et al., 2015; Sys et al., 2016). Knowledge on the behaviour of pulse fishers will provide the background to understand for instance the processes that affect the catch efficiency of the gear, provide insight in how pulse fishing activities affect local catch rates and provide insight in the impact on the benthic ecosystem.

It is common knowledge that a change in fishing technology improves either the catch efficiency of the fishing operations or reduces the cost of fishing (Eigaard et al., 2014). Changes in catch efficiency may have important consequences for the sustainable management of a fisheries, for instance due to the introduction of bias in the time series of catch per unit of effort as a measure of the trend in fish stock biomass (Quirijns et al., 2008). An improved catch efficiency may also give rise to an increased competition among fishing vessels. The transition of the otter trawl to the beam trawl in the flatfish fishery resulted in an arms race where new and more powerful beam trawlers outcompeted smaller vessels in catching sole (Rijnsdorp et al., 2008).

The catch efficiency of a gear is not only determined by the proportion of the fish in the path of the trawl that is caught, but also by the possibility to deploy the gear on the fishing grounds with the highest abundance of the target species. The location choice of a fishing vessel is expected to be a trade-off between the expected catch rate and species composition and the risk of damaging the gear. The analysis of high resolution information on the distribution of beam trawl vessels revealed that vessels avoided areas with a rough seafloor (Rijnsdorp et al., 1998; Hintzen et al., 2018). An analysis of the hot spots, areas where the fishers concentrated their fishing activities over several years, showed that beam trawlers targeting sole concentrated their trawling activities in warmer, shallow, dynamic, nearshore habitats, and within these specifically the depressions between sand ridges. Hotspots of beam trawlers targeting plaice occurred in the exposed, non-muddy flanks of the Dogger Bank and similar large-scale elevations (50-75 km) where especially the ridges of smaller sand banks are used. (van der Reijden et al., 2018).

A comparison of the spatial distribution of the pulse trawl fleet and the traditional beam trawl fleet showed that both fleets exploited similar fishing grounds although the fishing intensity in the German Bight has reduced and the intensity in the south-western North Sea has increased (Turenhout et al., 2016); (ICES, 2018). An analysis of the habitat preferences of the pulse and the traditional beam trawl showed subtle differences (Hintzen et al., in prep). The lack of clear differences in distribution between pulse and traditional beam trawlers contrast anecdotal information from the fishing industry 
that vessels that switched to pulse trawling were able to fish in specific areas (muddy grounds) where traditional vessels were unable to fish and where large concentrations of sole occurred.

In order to efficiently catch sole or plaice, fishers need to find the fishing grounds where the highest concentrations of their target species occur (Poos and Rijnsdorp, 2007a; Rijnsdorp et al., 2011). The areas varies seasonally due to the seasonal migrations between feeding and spawning areas and the annual offshore migration of young fish from the inshore nursery grounds. Superimposed on the seasonally varying distribution patterns, sole and plaice may temporarily concentrate in specific locations with a rich food availability (Shucksmith et al., 2006).

The fishing pattern of beam trawl vessels during a fishing trip has been studied by Rijnsdorp et al (2011) using detailed information on the location and catch rate of individual tows. They showed that a vessel alternates periods of searching, where the successive tows do not overlap, with periods of the exploitation of local grounds, where successive tows are taken close to each other. The catch rate of exploitation tows was significantly higher than during searching tows. During the exploitation period, the catch rate gradually decreased to the background catch rate of the searching tows.

In this study we analyse the location and catch rates of pulse trawlers reported for individual tows to describe the fishing patterns and compare these with the fishing patterns of traditional beam trawlers based on data collected in the first half of this century. We expect that pulse trawlers will show similar fishing patterns during a trip with alternating periods of searching and exploitation. However, since the catch efficiency of pulse trawlers for sole is higher, we expect that the rate at which the catch rate decreases during an exploitation event will be higher and that the duration of an exploitation event will be shorter. 


\section{$4 \quad$ Material and Methods}

\subsection{Logbook data}

Pulse trawl vessels.

A recording programme of the catch of the main target species and position per tow was set up in collaboration with the fishing industry. Data recording started on 1 January 2017 using a standardised input programme developed by Wouter van Broekhoven (VisNed) and Brita Trapman (Nederlandse Vissersbond). Data recording was restricted to the trips where the vessels deployed a pulse trawl. In this report, data were analysed that were collected in the period 1 January 2017 till 30 September 2018. The data set contains the following information for each tow: time at start and end of the tow, location of the start and end of the tow, catch $(\mathrm{kg})$ of sole, plaice, turbot+brill. The weights are estimated by the fishers. Weights are generally recorded with an precision of $5 \mathrm{~kg}$. The local Dutch time recorded by the fishers was converted to the winter time zone.

Weekly data sheets were collected by the producers organisations (PO's) and checked for errors in data format or missing information. In case of data problems the PO's contacted the skipper to solve the problem. Corrected data sets were send to Wageningen Marine Research where the data are stored in a central data base which is only accessible for authorised persons. To warrant the confidentiality of the data, the vessel identity in the data sets used for the analysis is replaced by a unique code. WMR ran another quality control check to test amongst other for the agreement of the reported catches and the total trip catch as reported by the skipper in the mandatory EU-logbook. Table 1 shows the number of trips which fulfilled the quality control criteria and were used in the present analysis. $22 \%$ of the trip data sets were not included in the analysis because of erroneous time recordings. Time constraints prevented the correction. Criteria for quality assurance were set high to avoid unnecessary noisy data for the analysis of the fishing patterns.

Tickler chain vessels.

A data set of catch weight of sole and plaice species and the positions per tow was available for beam trawl vessels from a previous study (Rijnsdorp et al., 2011). Here we used a selection of the fishing trips targeting sole with a mesh size of $80 \mathrm{~mm}$ which is restricted to the area south of $550 \mathrm{~N}$ - west of the $50 E$, and south of the $560 \mathrm{~N}$ - east of the $50 \mathrm{E}$.

The data set used in the current study contained information of just over 100 thousand tows of pulse trawlers and 86 thousand tows of traditional beam trawlers.

\subsection{Analysis of fishing patterns}

\subsubsection{Exploitation and searching tows}

The alteration of searching and exploitation was analysed using the approach of Rijnsdorp et al (2011). First we determined fishing grounds based on the spatial concentration of individual tows using a cluster analysis (R-function rdist.earth, library fields). This method forms disjunct clusters of tows based on geographic distance between two tow midpoints estimated according:

$$
d=60 * \sqrt{\left(y_{1}-y_{2}\right)^{2}+\left(x_{1} \cos \left(y_{1}\right)-x_{2} \cos \left(y_{2}\right)\right)^{2}}
$$

where $\mathrm{y} 1$ and $\mathrm{x} 1$ are the position latitude and longitude in decimal degrees of the first tow, and $\mathrm{y} 2$ and $\times 2$ are the position latitude and longitude in decimal degrees of the second tow. The distance is expressed in nautical miles. The analysis of single vessels yields an estimate of fishing grounds as 
perceived and exploited by individual vessels. Tow midpoints less than $\mathrm{h}$ nautical miles away from another tow midpoint were clustered with at least 2 other tows and considered to represent a fishing ground. These tows were interpreted to belong to an exploitation event. Tows that could not be clustered represent searching, while tows clustered with one other tow was considered to represent sampling. Figure 1 presents an illustration of the fishing pattern during a trip.

\subsubsection{Setting the distance criterion}

In their analysis of the BT data, Rijnsdorp et al (2011) set the distance criterion $\mathrm{h}$ at 4 nautical miles. The rationale for this choice was that it was the smallest distance at which the estimated contrast between the catch rate of the clustered tows and the non-clustered tows fell within the $95 \%$ confidence interval around the maximum contrast. They used the catch rate of sole and plaice combined as a proxy for the revenue.

Although the use of a constant distance criterion for all vessels is acceptable if the fleet is homogeneous with regard to the towing speed and haul duration, it is less appropriate if vessels vary in towing speed and haul duration. Because the PT and BT fleets studied here show clear differences in towing speed and haul duration, and also include both Euro cutters (221kW) and large vessels (about $441 \mathrm{~kW}$ ), we used a distance criterion for each individual vessel based on the observed mean haul duration of each vessel and the mean towing speed of their gear type (PT, BT) and engine class (Table 2).

\subsection{Catch rate during searching and exploitation}

The catch rate $(\mathrm{kg} /$ hour) by each tow $\mathrm{i}$ in trip $\mathrm{j}$ and vessel $\mathrm{k}$ was log transformed and standardised to the geometric mean catch rate during the trip.

\subsubsection{Decline in catch rate during exploitation}

The time trend in the catch $\left(c_{i j k}\right)$ of sole during exploitation events was analysed using a mixed effect model. We used a negative binomial distribution with a logarithmic link function to allow for overdispersion:

$$
\begin{gathered}
c_{i j k} \sim N B\left(\mu_{i j k} \theta\right) \\
\mu_{i j k}=\exp \left(n_{i j k}+\ln \left(d_{i j k}\right)\right)
\end{gathered}
$$

where $\mu_{i j k}$ is the expected catch in tow $\mathrm{i}$ in trip $\mathrm{j}$ of vessel $\mathrm{k}$, and $\theta$ is the dispersion parameter accounting for over-dispersion, $\ln \left(d_{i j k}\right)$ is the offset to take account of the differences in haul duration (d) of individual tows and $n_{i j k}$ is the linear predictor including both random effects for individual fishing grounds nested within ship and the following fixed effects.

$$
n_{i j k}=\alpha_{j k}+\beta_{1} t_{i j k}+\beta_{2} \sin \left(h_{i j k}\right)+\beta_{3} \cos \left(h_{i j k}\right)+\beta_{4} \ln \left(d_{i j k}\right)+\beta_{5} l_{i j k}
$$

In the fixed part of the model we also included haul duration because we observed that the catch rate decreases with increasing haul duration. To resolve convergence problems, $t_{i j k}$ was expressed in days and not in hours. Since most catches were recorded in multiples of $5 \mathrm{~kg}$, or sometimes even $10 \mathrm{~kg}$, the sole catch was converted into $5-\mathrm{kg}$ bins before analysis $(0=0 \mathrm{~kg}, 1=0-4 \mathrm{~kg}, 2=5-9 \mathrm{~kg}$, etc). This conversion affects the estimated intercept but does not affect the estimated rate of decline during exploitation.

The analysis was carried out with R version 3.3.0 (R core team 2016-05-03) and the Ime4 library. 


\subsection{Fishing patterns at the individual vessel level and the fleet level}

Fishing grounds may be exploited by one or more fishing vessels. To study the distribution of the fleet the fishing grounds of individual vessels (ic) were merged if the distance between any pair of tows of vessel $i$ and vessel $j$ was less than one nautical mile apart (fc). 


\section{$5 \quad$ Results}

\section{1 $\quad$ Fishing pattern of individual vessels}

The characteristics of the fishing patterns of pulse trawlers and traditional beam trawlers are very similar. Both pulse and beam trawlers have a higher catch rate ${ }^{1}$ during the exploitation of a fishing ground as compared to during searching or sampling (Table 3 ). The contrast in catch rate between exploitation and searching or sampling does not differ much between pulse trawling and beam trawling. The sole catch rate on a fishing ground is 0.217 times higher than during searching and sampling for PT and 0.229 higher for BT. For plaice the contrast is lower in particular for PT: 0.088 (PT) and 0.157 (BT). Vessels may leave a fishing ground and revisit the same ground later during the trip. The catch rate during the first visit is generally higher than during revisits during the same trip.

Pulse trawlers (PT) deployed $73 \%$ of their tows while exploiting a fishing ground as compared to $69 \%$ in traditional beam trawlers (BT). The proportion of tows spend searching (or sampling) by PT (21\% and $6 \%)$ is lower than in BT (24\% and $7 \%)$. The percentage of tows deployed while revisiting a fishing ground is lower in pulse trawling $(26 \%)$ than beam trawling $(31 \%)$.

The average number of tows taken during an exploitation event was quite variable among vessels (Figure 2). BT vessels took on average between 6 and 19 tows (median $=13.0$ ). The number of tows was higher for PT vessels. Large PT vessels took between 8 and 25 tows (median $=16.4$ ) and small PT vessels took between 8 and 27 tows (median $=18.8$ ).

The catch rate on a fishing ground was highest in the centre where tows are closer together than in more peripheral areas. Figure 3 shows that the catch rate in the centre of a fishing ground, estimated from the tows that are clustered at $h=1$, is on average 0.34 times higher than the back-ground catch rate and decreases to the back-ground catch rate in tows that are clustered at $k>=7$ nautical miles. The pattern in catch rate of BT and PT is very similar.

During an exploitation the average catch rate of sole decreased by -0.0369 ( $\mathrm{SE}=0.0139$ ) in small pulse trawlers and -0.0697 (SE $=0.0061$ ) in large pulse trawlers, corresponding to a decrease of $3.6 \%$ and $6.7 \%$ during a 24 hour period, respectively (Table 4 ). The rate of decline in catch rate in large beam trawlers was higher $(-0.162$, SE $=0.0192)$ corresponding to a decrease of $14.9 \%$ during a 24 hour period. The change in catch rate was estimated with a mixed effect model including a random intercept and slope for vessel / fishing ground, where fishing ground was nested within vessel. Including a random slope into the reference model improved the model fit. To take account of the diurnal pattern in catch rate observed in sole, the time of day (time) was included as ( $\sin ($ time) + $\cos ($ time $)$ ) in the fixed part of the model. $\log _{\mathrm{e}}$ transformed haul duration was included as an offset to estimate the time trend in the catch rate of sole. It was also included as a covariate in the fixed effect part of the model because the catch rate of sole was higher in short hauls.

The slope in catch rate estimated by the fixed part of the model represents the average slope of all fishing grounds observed in the data set. The variation in slope among vessels or trips among vessels, estimated by the random parts of the model, is relative small (Table 5). The variation in the slope among fishing grounds (ID.visit:ship in Table 5), however, is larger. The negative correlation between the random intercept and slope in catch rate among fishing grounds, which varies between -0.04 in BT and -0.37 in small PT, shows that the decline in catch rate is slightly faster on fishing grounds with a higher catch rate (Table 5).

\footnotetext{
${ }^{1}$ The catch rates presented in Table 3 are the relative catch rates during exploitation, searching and sampling tows relative to the mean catch rate over all tows during a trip.
} 
The analysis further showed that the catch rate of sole showed a diurnal pattern with highest catch rates observed around midnight and lowest catch rates during the day. The diurnal patterns estimated for the pulse trawlers and beam trawlers are quite similar, with the largest difference between day and night in Euro pulse trawlers (results not shown).

The decline in catch rate on a fishing ground was further explored by repeating the analysis for fishing grounds defined using a range of distance thresholds. Figure 4 shows that the decline in catch rate was faster when only tows are selected that cluster at a distance of $h=1$ nautical miles. Relaxing the distance criterion, thus including tows at a larger distance from the core of the fishing ground, reduced the estimated rate of decline in catch rate. The rate of decline was faster in BT as compared to PT irrespective of the distance criterion used.

No pattern in the distribution of the residuals was apparent (Appendix 1).

\subsection{Fishing patterns at the level of the fleet}

Of the 5850 fishing grounds distinguished during the study period, 3573 (61\%) were exploited by a single vessel and 2277 (39\%) were exploited by two or more vessels. Vessels differed in the proportion of fishing grounds shared with other (Figure 5a). The proportion fishing grounds shared with others ranged between 0.08-0.67. Fishing effort on shared fishing grounds was higher than on the fishing grounds exploited by a single vessel only. Of all exploitation tows, $51 \%$ were taken on shared fishing grounds. The proportion of tows taken on shared grounds ranged between 0.17 and 0.88 between individual vessels (Figure $5 \mathrm{~b}$ ). 


\section{Discussion}

This report presents the results of an intermediate analysis as it is based on the data collected up-to 30 September 2018. Because the logbook project is still ongoing, the results are preliminary and will be updated in the final report based on the complete data set that will become available at the end of this research project.

The fishing pattern of pulse trawlers closely resembles the pattern observed in traditional beam trawlers which comprises of alternating periods of searching and exploitation (Rijnsdorp et al., 2011). The exploitation tows occur closely together and reflect the exploitation of a single fishing ground. We interpret the difference in catch rate between exploitation and searching tows to reflect how the local fish density on a fishing ground is elevated relative to the back ground density. Pulse fishers experienced a difference in catch rate between exploitation and searching very similar to the difference experienced by beam trawlers, but the ratio between exploitation and searching tows was slightly higher in pulse trawlers. This suggests that pulse trawlers are able to continue fishing on a local fishing ground longer than a beam trawler. Comparison of the number of tows of an exploitation event between pulse and beam trawlers indeed showed that pulse trawlers took more tows on a fishing ground than beam trawlers, while they experienced a slower decline in catch rate than a beam trawler.

Although the differences in fishing patterns between PT and BT are internally consistent, they don't match the expected consequences of the higher catch efficiency of the PT reported by Poos et al. (in prep) and ICES (2018). As PT are almost 30\% more efficient to catch sole, one would expect a more rapid depletion of the sole biomass on a local fishing ground and a shorter stay on a fishing ground (shorter duration of the exploitation event and fewer tows). How can we understand these results?

The dynamics of a local aggregation of fish on a fishing ground is determined by the intricate interplay of the depletion due to exploitation and the immigration and emigration of fish. The local aggregations of beam trawl fishers are linked to local aggregations of their target species (Rijnsdorp et al., 2011; this study). These local aggregations are ephemeral and may disappear after a few days to a few weeks (Poos and Rijnsdorp, 2007a; Rijnsdorp et al., 2000b). We hypothesize that the dynamics of these local aggregations of fishing vessels reflect the dynamics of the local aggregations of fish, which reflect the occurrence of dense patches of food. The ephemeral character of the local aggregations of fishers may be due to the depletion of the food resources, for instance the spatfall of benthic invertebrates, by the flatfish.

If there is a local hotspot of food available, flatfish will immigrate in the area and gradually deplete their local food resources. The build-up of fish biomass will be slowed down when fishers aggregate in the area or may even decline if the exploitation rate exceeds the immigration rate. The situation, however, is more complex because fish also respond to fishing activities. Fish may be attracted to a fishing area because bottom trawling may enhance the food availability by damaging or killing benthos (scavengers), (Fonds and Groenewold, 2000; Kaiser and Spencer, 1994). On the other hand, fish may avoid the fisheries disturbance. Fish may swim away from a fishing ground, which will reduce the density of fish, or may avoid the fishing gear but remaining on the fishing ground. The latter mechanism is likely to play an important role in the interference competition between fishers (Gillis, 2003; Gillis and Peterman, 1998; Poos and Rijnsdorp, 2007b). Interference competition may have driven the arms race among beam trawlers since its introduction in the 1960s (Rijnsdorp et al., 2008) and may apply to the interactions between pulse trawlers and beam trawlers (Sys et al., 2016). The catch rate of a fisher, therefore, does not only depend on the density of fish but also to the density of fishing vessels. Increasing the number of fishing vessels on a fishing ground will result in a reduction of the catch rate due to interference competition (Poos and Rijnsdorp, 2007b; Rijnsdorp et al., 2000a). 
The difference between pulse and beam trawlers in the rate of decline in catch rate during the exploitation of a fishing ground will not only be affected by the exploitation rate - pulse trawlers being about 30\% more effective in catching sole (Poos et al., in prep) - but also by the number of vessels exploiting the same fishing ground. The decline in the size of the flatfish fleet may explain the slower decline in catch rate of pulse trawlers. The difference between pulse and beam trawlers may also be due to a difference in the response of sole to the trawling disturbance. Sole may be more likely to swim away from a fishing ground fished with heavy tickler chain beam trawl gear that are towed at a higher speed as compared to fishing grounds fished by pulse trawlers towing lighter gear at a lower towing speed.

The results of our analysis do not support the concerns raised by small scale fishers and environmental NGO's that pulse fishers deplete the local fishing grounds, because the catch rates of pulse trawl vessels appear to decrease at a slower rate than observed in traditional beam trawlers, and because pulse trawlers remain on a local grounds longer than traditional beam trawlers. However, because the lower catch rate of local fishers may be due to interference competition similar to the competition reported between Dutch pulse fishers and traditional Belgian beam trawlers (Sys et al., 2017) further analysis is needed to study the role of interference competition and the response of sole to trawling disturbance by beam trawls and pulse trawls.

In this report, we have focussed on the analysis of the fishing pattern of individual fishers. The results provide the detailed information on what happens on the local fishing grounds which is fundamental to assess the impact of the pulse trawl fishery and beam trawl fishery on the fisheries resources and on the benthic ecosystem. The next step will be to analyse the weekly fishing patterns of the whole fleet in order to estimate the dimensions of the fishing grounds and to explore how the fishing patterns of the fleet change from week to week. The study of the total pulse fleet provides a unique data set to study not only the dynamics of the whole fleet, including the interactions among pulse vessels, but also provides a solid basis to study competitive interactions with other fisheries. 


\section{$7 \quad$ Acknowledgments}

This study was funded by the ministry of Agriculture, Nature and Food security (project no. BO-43023.02-004). The individual data were collected under the responsibility of the Producers Organisations and fisheries organisations VisNed and Nederlandse Vissersbond. We thank Wouter van Broekhoven and Brita Trapman for their support in the data collection. 
Branch, T. A., Hilborn, R., and Bogazzi, E. 2005. Escaping the tyranny of the grid: a more realistic way of defining fishing opportunities. Canadian Journal of Fisheries and Aquatic Sciences, 62: 631642.

Eigaard, O. R., Bastardie, F., Hintzen, N. T., Buhl-Mortensen, L., Buhl-Mortensen, P., Catarino, R., Dinesen, G. E., et al. 2017. The footprint of bottom trawling in European waters: distribution, intensity, and seabed integrity. Ices Journal of Marine Science, 74: 847-865.

Eigaard, O. R., Marchal, P., Gislason, H., and Rijnsdorp, A. D. 2014. Technological Development and Fisheries Management. Reviews in Fisheries Science \& Aquaculture: 156-174.

Fonds, M., and Groenewold, S. 2000. Food subsidies generated by the beam trawl fisheries in the southern North Sea. In Effects of fishing on non-target species and habitats, pp. 130-150. Ed. by M. J. Kaiser, and S. J. de Groot. Blackwell Science, Oxford, UK.

Gillis, D. M. 2003. Ideal free distributions in fleet dynamics: a behavioral perspective on vessel movement in fisheries analysis. Canadian Journal of Zoology-Revue Canadienne De Zoologie, 81: 177-187.

Gillis, D. M., and Peterman, R. M. 1998. Implications of interference among fishing vessels and the ideal free distribution to the interpretation of CPUE. Canadian Journal of Fisheries and Aquatic Sciences, 55: 37-46.

Haasnoot, T., Kraan, M., and Bush, S. R. 2016. Fishing gear transitions: lessons from the Dutch flatfish pulse trawl. ICES Journal of Marine Science: Journal du Conseil, 73: 1235-1243.

Hintzen, N. T., Aarts, G., and Rijnsdorp, A. D. 2018. Persistence in the fine-scale distribution and spatial aggregation of fishing.

ICES. 2018. Report of the Working Group on Electric Trawling (WGELECTRA). 17-19 April 2018. IJmuiden, The Netherlands. ICES Document ICES CM 2018/EOSG:10.

Kaiser, M. J., and Spencer, B. E. 1994. Fish Scavenging Behavior in Recently Trawled Areas. Marine Ecology-Progress Series, 112: 41-49.

Poos, J. J., and Rijnsdorp, A. D. 2007a. The dynamics of small-scale patchiness of plaice and sole as reflected in the catch rates of the Dutch beam trawl fleet and its implications for the fleet dynamics. Journal of Sea Research, 58: 100-112.

Poos, J. J., and Rijnsdorp, A. D. 2007b. An "experiment" on effort allocation of fishing vessels: the role of interference competition and area specialization. Canadian Journal of Fisheries and Aquatic Sciences, 64: 304-313.

Quirijns, F. J., Poos, J. J., and Rijnsdorp, A. D. 2008. Standardizing commercial CPUE data in monitoring stock dynamics: Accounting for targeting behaviour in mixed fisheries. Fisheries Research, 89: 1-8.

Rijnsdorp, A. D., Buys, A. M., Storbeck, F., and Visser, E. G. 1998. Micro-scale distribution of beam trawl effort in the southern North Sea between 1993 and 1996 in relation to the trawling frequency of the sea bed and the impact on benthic organisms. Ices Journal of Marine Science, 55: 403-419.

Rijnsdorp, A. D., Dol, W., Hoyer, M., and Pastoors, M. A. 2000a. Effects of fishing power and competitive interactions among vessels on the effort allocation on the trip level of the Dutch beam trawl fleet. Ices Journal of Marine Science, 57: 927-937.

Rijnsdorp, A. D., Poos, J. J., and Quirijns, F. J. 2011. Spatial dimension and exploitation dynamics of local fishing grounds by fishers targeting several flatfish species. Canadian Journal of Fisheries and Aquatic Sciences, 68: 1064-1076.

Rijnsdorp, A. D., Poos, J. J., Quirijns, F. J., HilleRisLambers, R., de Wilde, J. W., and Den Heijer, W. M. 2008. The arms race between fishers. Journal of Sea Research, 60: 126-138.

Rijnsdorp, A. D., van Maurik Broekman, P. L., and Visser, E. G. 2000b. Competitive interactions among beam trawlers exploiting local patches of flatfish in the North Sea. Ices Journal of Marine Science, 57: 894-902.

Shucksmith, R., Hinz, H., Bergmann, M., and Kaiser, M. J. 2006. Evaluation of habitat use by adult plaice (Pleuronectes platessa L.) using underwater video survey techniques. Journal of Sea Research, 56: 317-328.

Sys, K., Poos, J. J., Van Meensel, J., Polet, H., and Buysse, J. 2016. Competitive interactions between two fishing fleets in the North Sea. ICES Journal of Marine Science: Journal du Conseil, 73 1485-1493

Turenhout, M. N. J., Zaalmink, B. W., Strietman, W. J., and Hamon, K. G. 2016. Pulse fisheries in the Netherlands; Economic and spatial impact study.: 2016-104. 32 pp.

van Denderen, P. D., Hintzen, N. T., Van Kooten, T., and Rijnsdorp, A. D. 2015. Temporal aggregation of bottom trawling and its implication for the impact on the benthic ecosystem. Ices Journal of Marine Science, 72: 952-961.

van der Reijden, K. J., Hintzen, N. T., Govers, L. L., Rijnsdorp, A. D., and Olff, H. 2018. North Sea demersal fisheries prefer specific benthic habitats. PLoS ONE, 13: e0208338. 

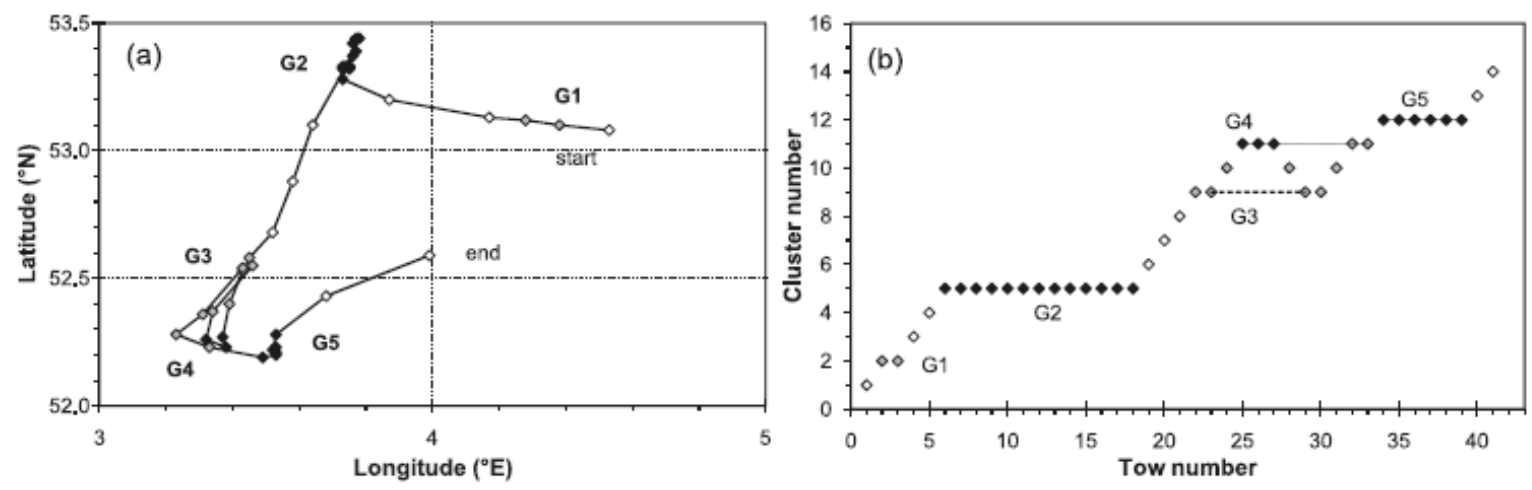

Figure 1. Illustration of the tow midpoints recorded during a fishing trip (a) and the results of the cluster analysis (b) showing five clusters of two or more successive tows that represent three fishing grounds (G2, G4 and G5) with at least three successive tows, and two sampled grounds (G1, G3) with two successive tows. Tows were clustered using a distance criterion of $h=4$ nautical miles (from Rijnsdorp et al. 2011). 

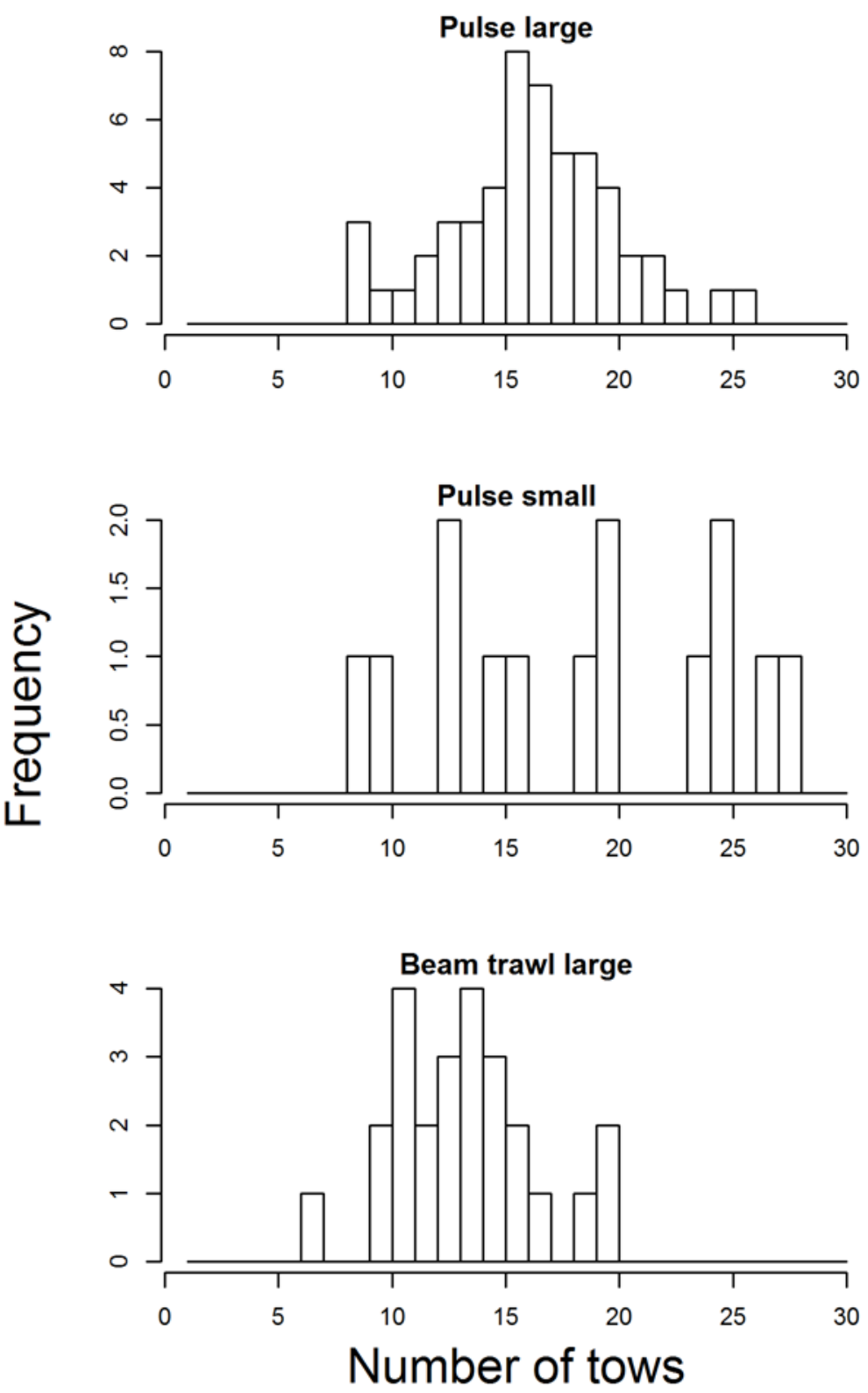

Figure 2. Frequency distribution of the average number of tows during an exploitation event of large and small pulse trawlers and large beam trawlers. The analysis used a distance criterion scaled proportional to a two hour tow at 6.5 nautical miles.hour-1 of a reference beam trawl vessel (see text). Only vessels included with $>=10$ exploitation events recorded. 


\section{scaled to back ground catch rate at $>=7 \mathrm{~nm}$}

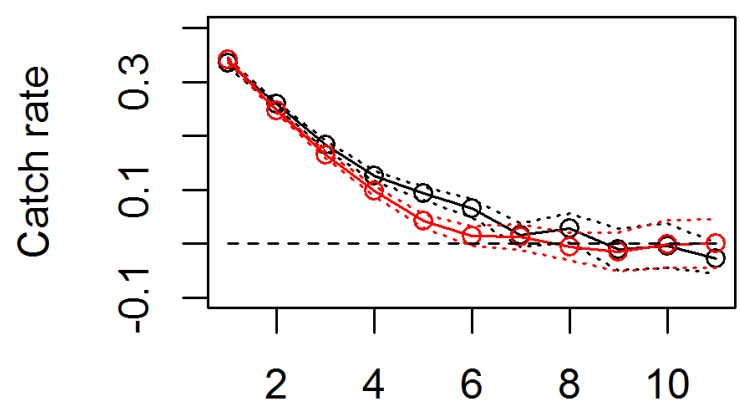

Distance (nautical miles)

Figure 3. Mean and $95 \%$ confidence interval of the catch rate of sole of tows by pulse trawlers (red) and beam trawlers (black) at an increasing distance to the core fishing ground. The core fishing ground was defined by the tows that were clustered at a distance criterion of $h=1$ nautical mile. The horizontal dashed line shows the background catch rate in the tows that were not clusters at a distance $<7$ nautical miles.

\section{Sole}

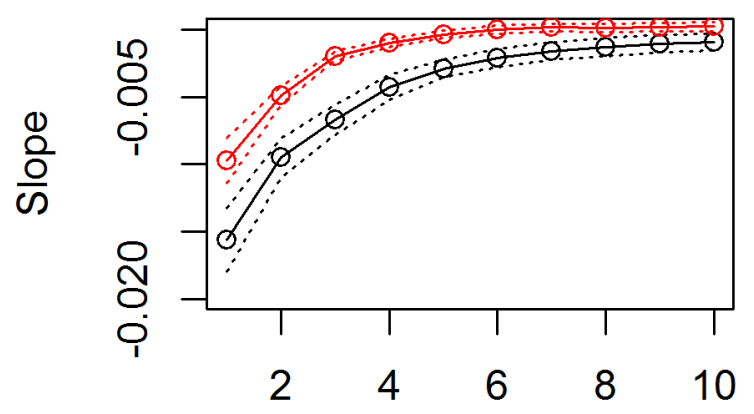

Distance (nautical miles)

Figure 4. Relationship between the estimated rate of decline $\left(\mathrm{h}^{-1}\right)$ in catch rate of sole during an exploitation event for exploitation events determined with a distance criterion ranging between $h=1$ and $\mathrm{h}=10$ nautical miles for pulse trawlers (red) and beam trawlers (black). 

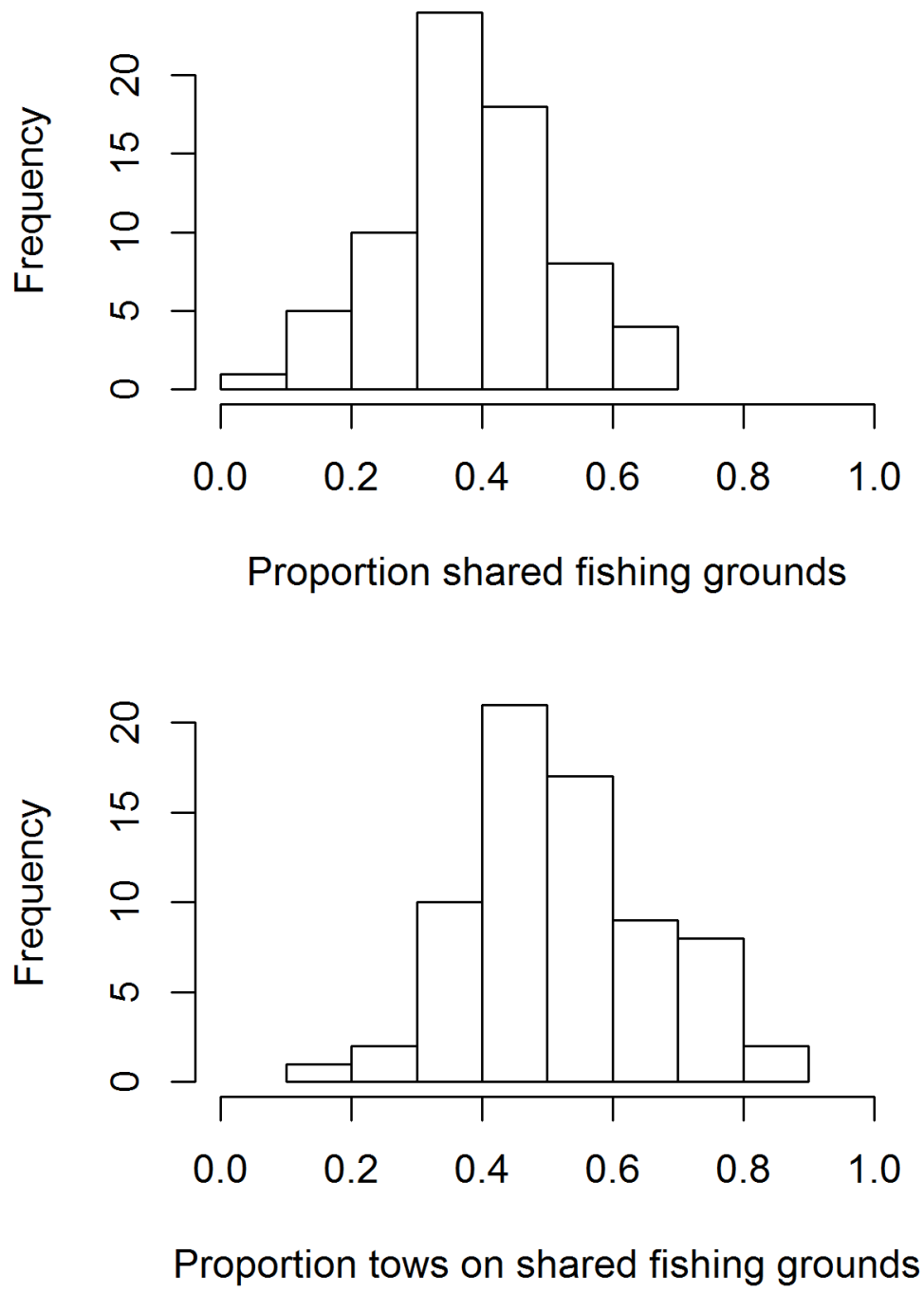

Figure 5. Frequency distribution of (top panel) the proportion of fishing grounds of individual vessels shared with at least one other vessel and (bottom panel) the proportion of exploitation tows of individual vessels taken on shared fishing grounds. 
Table 1. Overview of the coverage of the Dutch ${ }^{1)}$ pulse trawl fleet targeting sole for which detailed logbook data have been collected in the period between 1-1-2017 and 30-9-2018.

Logbook data per tow

$\begin{array}{ccc}\text { Number } & \text { Number } & \text { Number } \\ \text { of vessels } & \text { of vessels } & \text { of tows }\end{array}$

\begin{tabular}{lccccc}
\hline & $2017-2018$ & 2017 & 2018 & 2017 & 2018 \\
Vessel class & & & & & 17239 \\
\hline Euro cutters & 19 & 16 & 13 & 61409 & 12301 \\
Large vessels & 58 & 52 & 53 & 46941 \\
\hline
\end{tabular}

1) Including two flag vessels

Table 2. Mean towing speed of beam trawlers and pulse trawlers (from ICES WGELECTRA, 2018)

\begin{tabular}{lcc} 
& \multicolumn{2}{c}{ Towing speed (nautical miles.hour $\left.{ }^{-1}\right)$} \\
\cline { 2 - 3 } & Large $(>221 \mathrm{~kW})$ & Small $(<=221 \mathrm{~kW})$ \\
\hline Beam trawl & 6.31 & 5.36 \\
Pulse trawl & 4.90 & 4.63 \\
\hline
\end{tabular}


Table 3. Average $\log _{\mathrm{e}}$ transformed catch rate relative to geometric mean catch rate during the trip of sole, plaice and revenue ( $4 *$ sole + plaice) in exploitation, sampling and searching tows, and during exploitation tows of successive visits (visit $=1$ to 5 ) to the same fishing ground in the same fishing trip. The relative catch rate during searching and sampling tows is presented under visit $=0$.

\begin{tabular}{|c|c|c|c|c|c|c|c|}
\hline & \multicolumn{2}{|c|}{ Sole } & \multicolumn{2}{|c|}{ Plaice } & \multicolumn{2}{|c|}{ Revenue } & \multirow[b]{2}{*}{$\mathrm{n}$} \\
\hline & Cpue & SD & Cpue & SD & Cpue & SD & \\
\hline \multicolumn{8}{|c|}{ Beam trawlers (BT-large) } \\
\hline Exploitation & 0.0693 & 0.4742 & 0.0463 & 0.7982 & 0.0751 & 0.4863 & 52712 \\
\hline Sampling & -0.0846 & 0.5841 & -0.0483 & 0.9335 & -0.0835 & 0.6767 & 5632 \\
\hline Searching & -0.1724 & 0.6766 & -0.1177 & 0.9811 & -0.1893 & 0.8008 & 18439 \\
\hline \multicolumn{8}{|l|}{ Visit } \\
\hline 0 & -0.1518 & 0.6571 & -0.1015 & 0.9706 & -0.1645 & 0.7749 & 24071 \\
\hline 1 & 0.0771 & 0.4805 & 0.0551 & 0.8269 & 0.0873 & 0.4873 & 36172 \\
\hline 2 & 0.0649 & 0.4671 & 0.0264 & 0.7430 & 0.0603 & 0.4886 & 11899 \\
\hline 3 & 0.0227 & 0.4466 & 0.0347 & 0.7113 & 0.0236 & 0.4784 & 3342 \\
\hline 4 & 0.0206 & 0.4083 & -0.0294 & 0.6670 & 0.0011 & 0.4186 & 995 \\
\hline 5 & -0.0014 & 0.4454 & 0.1550 & 0.6537 & 0.0227 & 0.4991 & 304 \\
\hline \multicolumn{8}{|c|}{ Pulse trawlers (PT-large) } \\
\hline Exploitation & 0.0581 & 0.3875 & 0.0236 & 0.8230 & 0.0576 & 0.3811 & 58756 \\
\hline Sampling & -0.1011 & 0.4436 & -0.0008 & 0.9108 & -0.0872 & 0.4379 & 4988 \\
\hline Searching & -0.1760 & 0.4971 & -0.0838 & 0.9282 & -0.1784 & 0.5066 & 16525 \\
\hline \multicolumn{8}{|l|}{ Visit } \\
\hline 0 & -0.1586 & 0.4862 & -0.0646 & 0.9249 & -0.1573 & 0.4930 & 21513 \\
\hline 1 & 0.0630 & 0.3913 & 0.0365 & 0.8150 & 0.0657 & 0.3727 & 43582 \\
\hline 2 & 0.0466 & 0.3863 & -0.0069 & 0.8540 & 0.0398 & 0.4150 & 11574 \\
\hline 3 & 0.0419 & 0.3357 & -0.0340 & 0.7690 & 0.0205 & 0.3591 & 2723 \\
\hline 4 & 0.0317 & 0.3008 & -0.0231 & 0.9715 & 0.0244 & 0.2797 & 691 \\
\hline 5 & -0.0456 & 0.4996 & -0.0685 & 0.8076 & -0.0598 & 0.6011 & 186 \\
\hline \multicolumn{8}{|c|}{ Pulse trawlers (BT-small) } \\
\hline Exploitation & 0.0554 & 0.4172 & 0.0466 & 1.1642 & 0.0600 & 0.4397 & 13786 \\
\hline Sampling & -0.1390 & 0.5147 & -0.0963 & 1.2206 & -0.1532 & 0.5827 & 1200 \\
\hline Searching & -0.1847 & 0.4911 & -0.1627 & 1.2418 & -0.1988 & 0.5525 & 3234 \\
\hline \multicolumn{8}{|l|}{ Visit } \\
\hline 0 & -0.1723 & 0.4980 & -0.1448 & 1.2363 & -0.1865 & 0.5611 & 4434 \\
\hline 1 & 0.0718 & 0.4070 & 0.0877 & 1.1681 & 0.0807 & 0.4251 & 7502 \\
\hline 2 & 0.0470 & 0.4257 & 0.0395 & 1.1361 & 0.0521 & 0.4486 & 3837 \\
\hline 3 & 0.0165 & 0.4407 & -0.0754 & 1.1393 & 0.0030 & 0.4938 & 1725 \\
\hline 4 & 0.0320 & 0.3997 & -0.1380 & 1.1330 & 0.0094 & 0.3766 & 548 \\
\hline 5 & -0.0056 & 0.4416 & 0.2187 & 1.6935 & 0.0640 & 0.4112 & 174 \\
\hline
\end{tabular}


Table 4. The average catch rate ( $5 \mathrm{~kg}$ bins) at the start of an exploitation event (intercept) and the rate of decline (tvisit, day ${ }^{-1}$ ) during an exploitation event of large BT, large PT and small PT as estimated with the mixed effect model including random effects for vessel and fishing ground, and fixed effects for time elapsed since start of fishing on a fishing ground (tvisit, days), time of day (time, hours) and haul duration (hldur, hours). The sin(time) and $\cos$ (time) estimate the diurnal pattern in catch rate.

\begin{tabular}{|c|c|c|c|c|}
\hline & Value & Std.Error & z-value & $p$-value \\
\hline \multicolumn{5}{|c|}{ BT - Beam trawl (large) } \\
\hline (Intercept) & 1.49323 & 0.16589 & 9.001 & $<2 \mathrm{e}-16$ \\
\hline tvisit & -0.16151 & 0.01917 & -8.423 & $<2 \mathrm{e}-16$ \\
\hline $\sin ($ time) & 0.02607 & 0.00223 & 11.67 & $<2 \mathrm{e}-16$ \\
\hline $\cos$ (time) & 0.05047 & 0.00217 & 23.293 & $<2 \mathrm{e}-16$ \\
\hline In(hldur) & -0.57881 & 0.02080 & -27.735 & $<2 \mathrm{e}-16$ \\
\hline \multicolumn{5}{|c|}{ PT - Pulse trawl (large) } \\
\hline (Intercept) & 0.60472 & 0.06369 & 9.494 & $<2 \mathrm{e}-16$ \\
\hline tvisit & -0.06967 & 0.00614 & -11.334 & $<2 \mathrm{e}-16$ \\
\hline $\sin ($ time) & 0.01340 & 0.00171 & 7.818 & $5.38 \mathrm{E}-15$ \\
\hline cos(time) & 0.06354 & 0.00171 & 37.081 & $<2 \mathrm{e}-16$ \\
\hline In(hldur) & -0.62099 & 0.01197 & -51.868 & $<2 \mathrm{e}-16$ \\
\hline \multicolumn{5}{|c|}{ PT - Pulse trawl (small) } \\
\hline (Intercept) & -0.04038 & 0.09285 & -0.435 & 0.66367 \\
\hline tvisit & -0.03686 & 0.01391 & -2.651 & 0.00803 \\
\hline $\sin ($ time) & 0.01001 & 0.00526 & 1.904 & 0.05694 \\
\hline $\cos ($ time $)$ & 0.07797 & 0.00522 & 14.936 & $<2 \mathrm{e}-16$ \\
\hline In(hldur) & -0.57060 & 0.02010 & -28.394 & $<2 \mathrm{e}-16$ \\
\hline
\end{tabular}


Table 5. Estimates of the random effects of the mixed effect model of catch rate of sole

\begin{tabular}{|c|c|c|c|c|}
\hline Groups & Name & Variance & Std.Dev. & Corr \\
\hline \multicolumn{5}{|c|}{ Beam trawlers (BT) } \\
\hline \multirow[t]{2}{*}{ ID.visit:ship } & (Intercept) & 0.28293 & 0.53191 & \\
\hline & tvisit & 0.05403 & 0.23244 & -0.04 \\
\hline \multirow[t]{2}{*}{ ship } & (Intercept) & 1.70723 & 1.30661 & \\
\hline & tvisit & 0.00542 & 0.07362 & 0.46 \\
\hline \multicolumn{5}{|c|}{ Pulse trawlers (PT): large } \\
\hline \multirow[t]{2}{*}{ ID.visit:ship } & (Intercept) & 0.14608 & 0.38221 & \\
\hline & tvisit & 0.01576 & 0.12557 & -0.19 \\
\hline \multirow[t]{2}{*}{ ship } & (Intercept) & 0.12122 & 0.34817 & \\
\hline & tvisit & 0.00071 & 0.02665 & -0.51 \\
\hline \multicolumn{5}{|c|}{ Pulse trawlers (PT): small } \\
\hline \multirow[t]{2}{*}{ ID.visit:ship } & (Intercept) & 0.08657 & 0.29423 & \\
\hline & tvisit & 0.01551 & 0.12455 & -0.37 \\
\hline \multirow[t]{2}{*}{ ship } & (Intercept) & 0.02384 & 0.15440 & \\
\hline & tvisit & 0.00033 & 0.01806 & 1 \\
\hline
\end{tabular}


Appendix 1. Residual plots of the NB-glmer analysis of the slope in sole catch during the exploitation of a fishing ground for large pulse trawlers, small pulse trawlers and traditional beam trawlers.
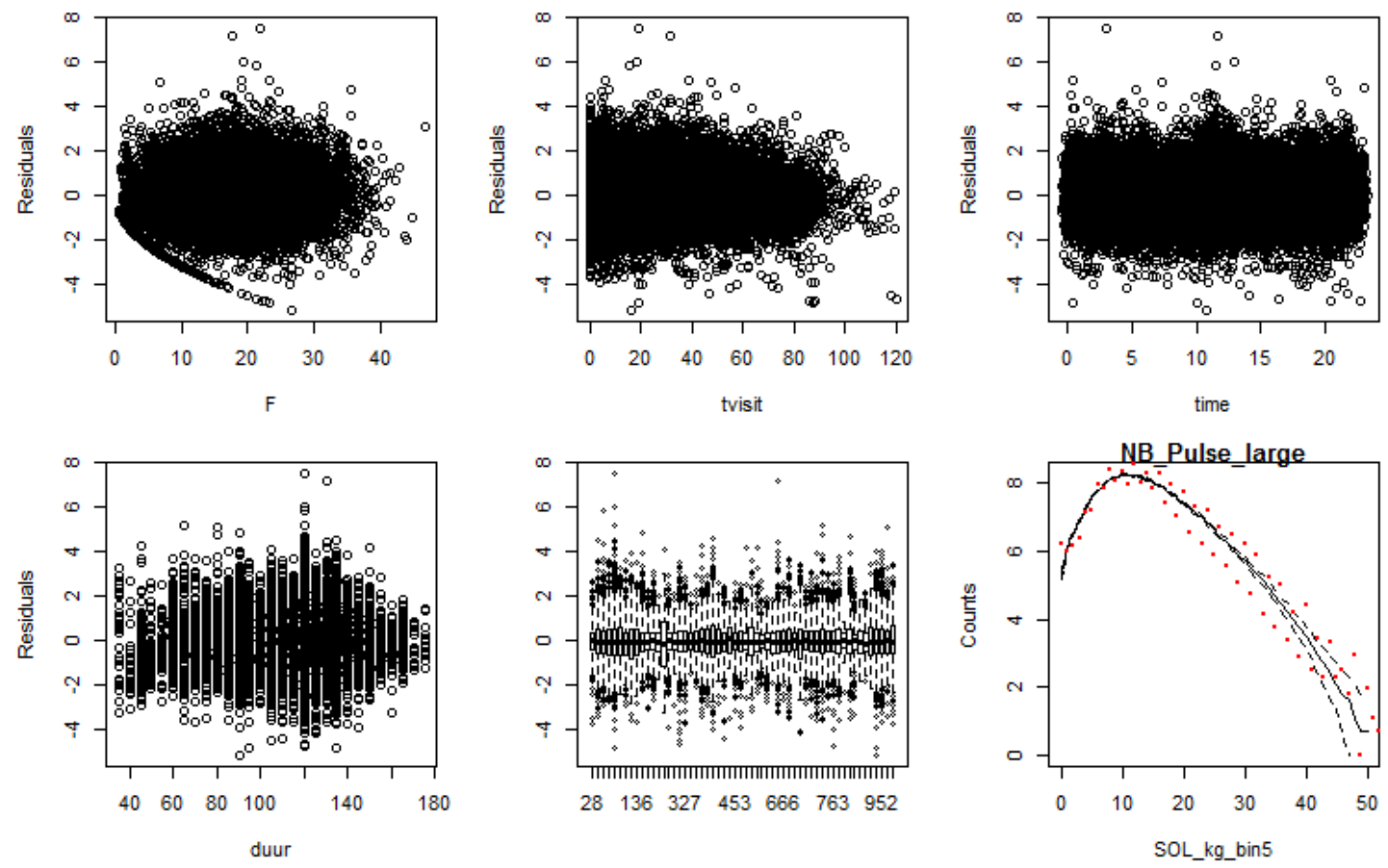

Figure A1. Residual plots of the glmer analysis for large pulse trawlers
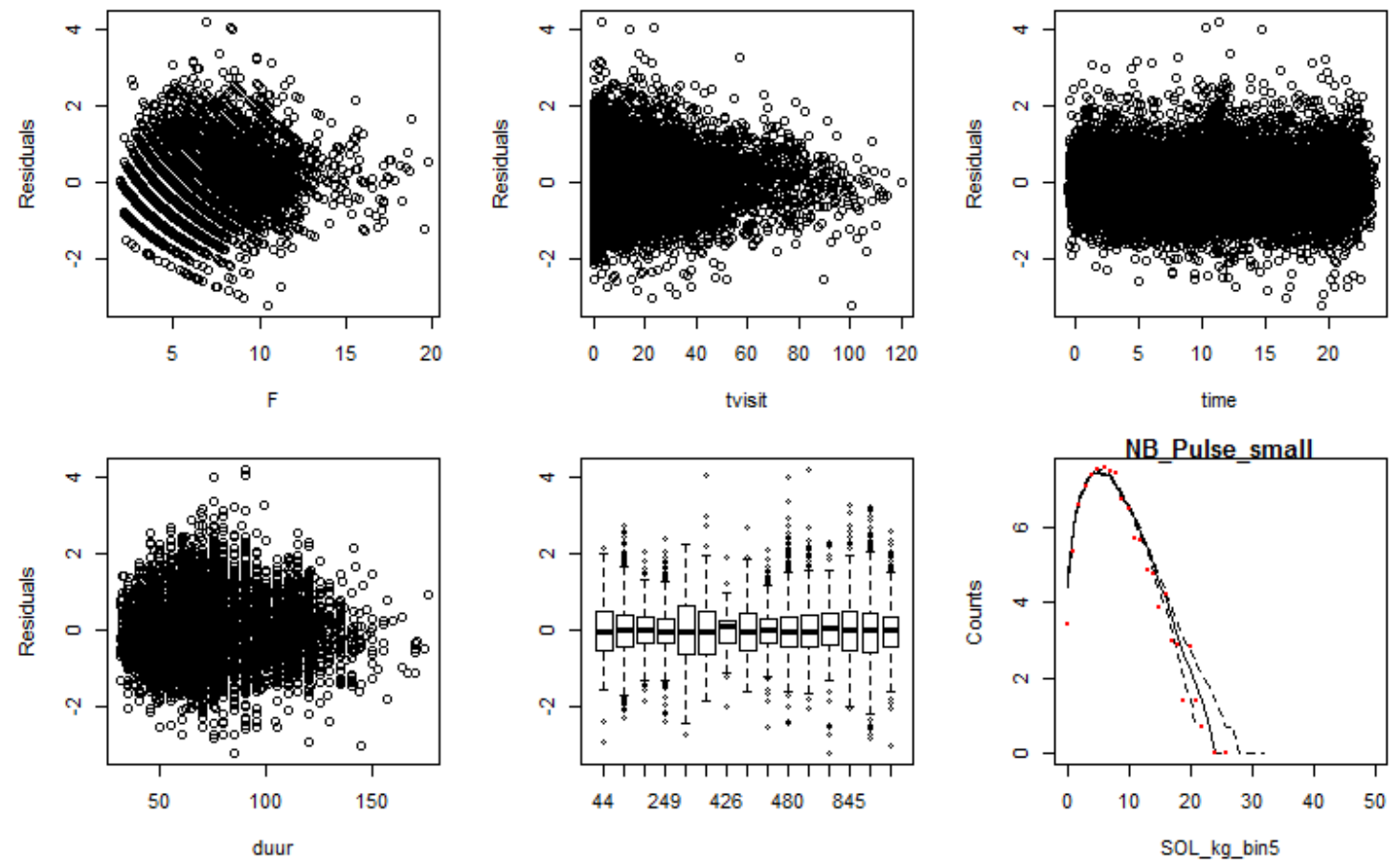

Figure A2. Residual plots of the glmer analysis for small pulse trawlers 

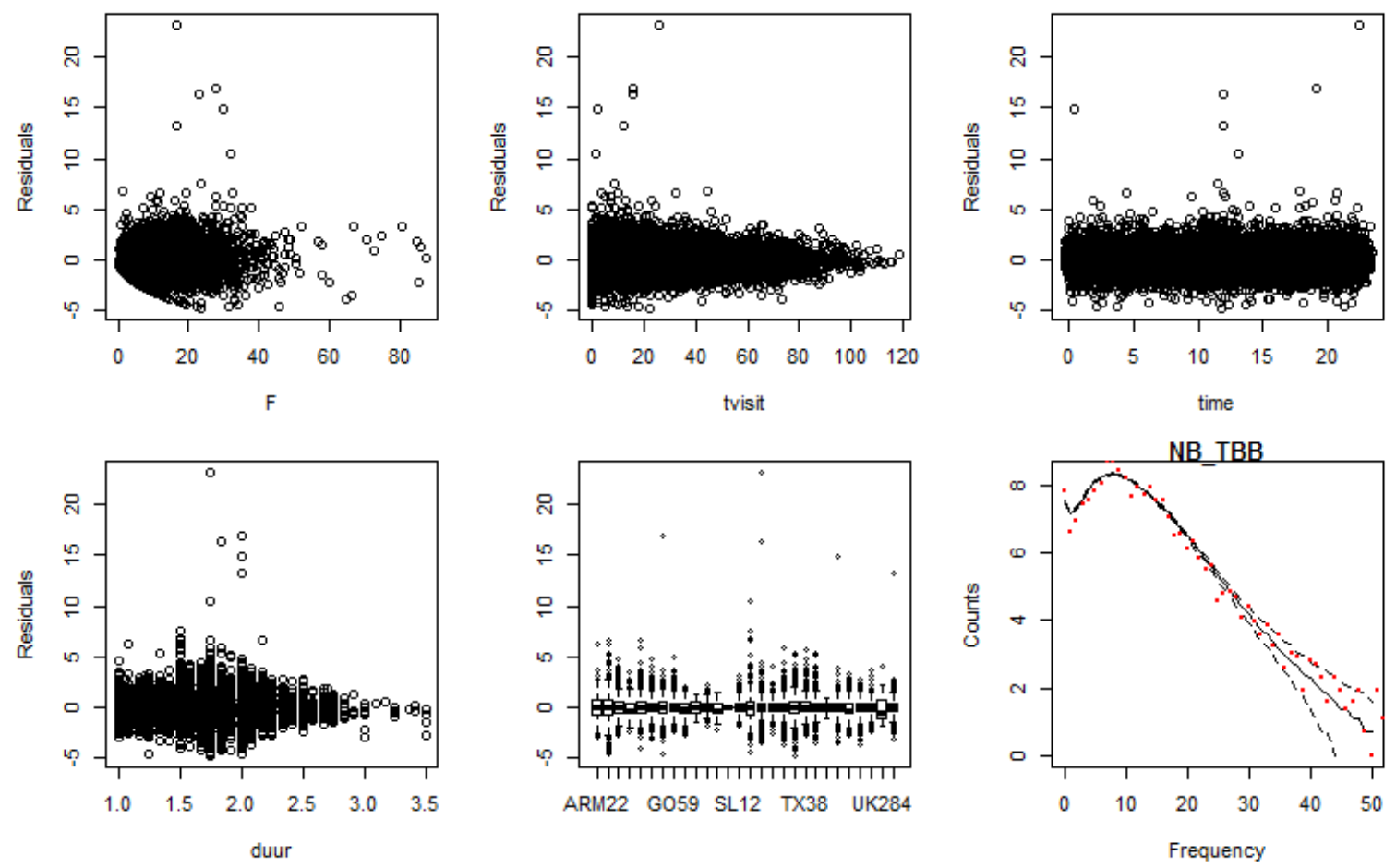

Figure A3. Residual plots of the glmer analysis for traditional beam trawlers (BT) 


\section{Quality Assurance}

Wageningen Marine Research utilises an ISO 9001:2015 certified quality management system. This certificate is valid until 15 December 2021. The organisation has been certified since 27 February 2001. The certification was issued by DNV GL.

Furthermore, the chemical laboratory at IJmuiden has NEN-EN-ISO/IEC 17025:2005 accreditation for test laboratories with number L097. This accreditation is valid until $1^{\text {th }}$ of April 2021 and was first issued on 27 March 1997. Accreditation was granted by the Council for Accreditation. The chemical laboratory at IJmuiden has thus demonstrated its ability to provide valid results according a technically competent manner and to work according to the ISO 17025 standard. The scope (L097) of de accredited analytical methods can be found at the website of the Council for Accreditation (www.rva.nl).

On the basis of this accreditation, the quality characteristic $Q$ is awarded to the results of those components which are incorporated in the scope, provided they comply with all quality requirements. The quality characteristic $Q$ is stated in the tables with the results. If, the quality characteristic $Q$ is not mentioned, the reason why is explained.

The quality of the test methods is ensured in various ways. The accuracy of the analysis is regularly assessed by participation in inter-laboratory performance studies including those organized by QUASIMEME. If no inter-laboratory study is available, a second-level control is performed. In addition, a first-level control is performed for each series of measurements.

In addition to the line controls the following general quality controls are carried out:

- Blank research.

- Recovery.

- Internal standard

- Injection standard.

- Sensitivity.

The above controls are described in Wageningen Marine Research working instruction ISW 2.10.2.105. If desired, information regarding the performance characteristics of the analytical methods is available at the chemical laboratory at IJmuiden.

If the quality cannot be guaranteed, appropriate measures are taken. 


\section{Justification}

Report C030/19

Project Number: 4318200064

The scientific quality of this report has been peer reviewed by a colleague scientist and a member of the Management Team of Wageningen Marine Research

Approved: $\quad$ Edward Schram

Researcher

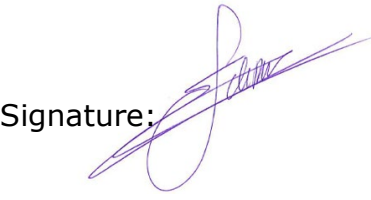

Date: $\quad 10$ april 2019

Approved: $\quad$ Tammo Bult

Director

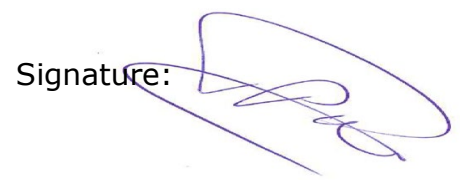

Date: $\quad 10$ april 2019 
Wageningen Marine Research

T +31(0)317480900

E: marine-research@wur.nl

www.wur.eu/marine-research

Visitors' address

- Ankerpark 271781 AG Den Helder

- Korringaweg 7, 4401 NT Yerseke

- Haringkade 1, 1976 CP IJmuiden
With knowledge, independent scientific research and advice, Wageningen Marine Research substantially contributes to more sustainable and more careful management, use and protection of natural riches in marine, coastal and freshwater areas.

Wageningen Marine Research is part of Wageningen University \& Research. Wageningen University \& Research is the collaboration between Wageningen University and the Wageningen Research Foundation and its mission is: 'To explore the potential for improving the quality of life' 